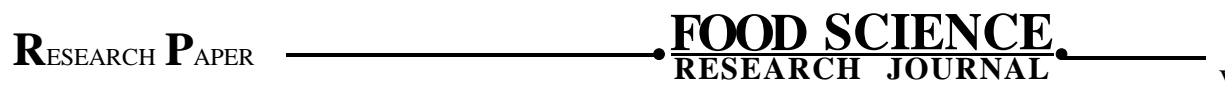

e ISSN-2230-9403 Visit us : www. researchjournal.co.in Volume 7 | Issue 2 | October, 2016 | 190-194

DOI : $10.15740 / \mathrm{HAS} / \mathrm{FSRJ} / 7.2 / 190-194$

\title{
Material balance, proximate and functional analysis of green banana flour prepared by cabinet drying method
}

\author{
P.P. Thakur, V.S. Pawar AND D.M. Shere
}

\begin{abstract}
Material balance of the process involved in preparation of green banana flour is an important aspect to be overlooked. Unripe green banana flour prepared by pretreatment of banana slices with sodium metabisulphite followed by cabinet drying method, produced a flour with fairly white colour, good nutritive value and also yield was about 26 per cent. Proximate composition and functional properties such as bulk density, water absorption capacity, swelling capacity, foaming capacity, emulsification capacity and rehydration characteristics of prepared banana flour were determined. Also cost of production of banana flour was about Rs. 9.50/100g which is much less than any other advanced processing technique and is quite affordable.
\end{abstract}

Key Words : Green Banana, Sodium metabisulphite, Cabinet drying, Yield

How to cite this article : Thakur, P.P., Pawar, V.S. and Shere, D.M. (2016). Material balance, proximate and functional analysis of green banana flour prepared by cabinet drying method. Food Sci. Res. J., 7(2): 190-194, DOI : 10.15740/HAS/FSRJ/7.2/190-194.

P.P. THAKUR, Department of Food Science and Technology, Vasantrao Naik

Marathwada Krishi Vidyapeeth, PARBHANI (M.S.) INDIA

Email : preeti_gautam2007@rediffmail.com

Associate Authors' :

V.S. PAWAR AND D.M. SHERE, Department of Food Science and Technology,

Vasantrao Naik Marathwada Krishi Vidyapeeth, PARBHANI (M.S.) INDIA 